\title{
IN SEARCH OF DIPLOMATIC GIFTS - ON A GROUP OF 18TH CENTURY POLISH PORCELAIN IN THE TOPKAPI PALACE COLLECTION
}

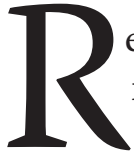

elations between the Polish-Lithuanian Commonwealth and the Ottoman Empire were quite close. Starting in the 15th century, with some mutual treaties, the relations between two countries often took on peaceful lines, despite the wars and conflicts intervening in between. It is accepted that the first Polish envoy was sent to establish diplomatic relations between the two countries during the reign of Mehmed I. (Çelebi Mehmed). And others followed. From the end of the 18th century until its dissolution, around 150 envoys visited the Ottoman Empire from Poland. ${ }^{1)}$ In the 18th century, the Ottoman Empire started to send delegations of envoys to Poland. ${ }^{2)}$ This is the manner in which the political, commercial and cultural dimension of such relations have been determined.

Envoys were indispensable for diplomatic relations between countries. They were sent to congratulate and report the ascension of kings and sultans to their thrones, concluding post-war treaties and determining the terms of commerce between the countries. Envoys were appointed for both long and short terms. Expanding over three continents after the 15th century, the Ottoman Empire continued its political relations with the surrounding countries of political importance and accepted many envoys from Eastern and Western palaces. Envoys had been sent to various countries since the foundation of

1) For detailed information see Reychman (1964a); Kołodziejczyk (1999); Majda (2014).

2) Reychman (1964a:12). 
the empire. ${ }^{3)}$ Many were sent to several European capitals in line with the European diplomacy that had come into prominence, particularly in the 18th century. The reports written by the envoys are quite important, in that they indirectly reveal the history of the period, with all the details. Paintings by European artists visualized these events together with the issues they dealt with. ${ }^{4)}$ These inform us about how the envoys were accepted in European palaces.

Ottoman envoys to be sent to Europe were elected from among a variety of well-trained bureaucrats. They had to be capable of collecting information, be good observers, be smart and have common sense. In particular, those who were able to represent the might of the Ottoman state were preferred. The Grand Vizier, who was required to appear before the Sultan, and then set off after receiving letters and verbal information, accompanied the envoy whose mission was specified. ${ }^{5)}$ In the host country, official guides and interpreters were assigned to accompany the envoys. The acceptance of an Ottoman envoy into European palaces was far easier than acceptance to the Ottoman palace, depending on the balance of power. The community of the nobility, consisting of men, women, and children, watched the procession of envoys with great pleasure. There is no doubt that these delegations of envoys played an important role in increasing the Oriental trends in Europe in the 18th century. ${ }^{6)}$

Offering gifts plays an important role in achieving goals in diplomatic missions. Winning the hearts of others with gifts has been a tradition since ancient times, in the palaces of the East and the West. These gifts can be seen as symbols of power and the desire for reconciliation. ${ }^{7)}$ The gifts presented to the Ottoman court vary according to the periods and regions. While gifts such as precious fabrics, jewellery and watches were common in 16th and 17th centuries, dining sets, mirrors, chandeliers or various furniture were added to these gifts in the 18th century. With regards to Poland, fur and amber were the main gifts offered by their envoys in the 16th century. The favourite gifts from the 18th century were porcelain and clocks. With the establishment of large factories, the aim of 18th century gifts made to suit the Turkish taste was, of course, to create a commercial market. Carpets, fabrics, horses, horse

3) Tufan (2014: 196).

4) Renda (2014:37-39).

5) Unat (1987:23, 28, 30-31); Topaktaş (2011:31).

6) Renda (2014: 38, 41).

7) Hitzel (2010:249). 
harnesses, swords, archery sets, and caftans in particular, were usually sent as gifts from the Ottoman court to Europe in return. ${ }^{8)}$

The core of this study is to present what the last envoy of the Ottomans in Poland, Seyyid Numan Bey (Numan Enis Bey), took with him during his stay in Warsaw in the 18th century. With this example, our aim is to explain the important role of gifts in diplomatic relations. The gifts sent from the King to the Sultan and from the Sultan to the King with Numan Bey, are not only important for the history of politics, but they also shed light on the history of commerce, culture and art.

Sultan Abdulhamid I sent Sayyid Numan Bey to Warsaw in 1777. The main task of the envoy was to seek cooperation with Poland against Russia, which was considered as the common enemy after the Treaty of Küçük Kaynarca. But in the end, this was a fruitless attempt to find an alliance. Other aims of the Embassy, were to announce the enthronement of Abdulhamid I (Reigned from 21 fanuary 1774 to 6 or 7 April 1789), and to congratulate King Stanislaw August Poniatowski on his accession to the throne (Reigned from 12 September 1764-7 February 1798). There is little information on Numan Bey, the last envoy to the Polish-Lithuanian Commonwealth, in the Ottoman records. What is certainly known, is that he was an educated bureaucrat, received some diplomatic missions, and after his being an envoy, was appointed as Chief Bookkeeper. ${ }^{9}$

In the Ottoman archive documents dated 4 to 5 May 1777, 3 December 1777 and another dating from 1777, it is stated that some precious goods and items were entrusted to Sayyid Numan Bey from the palace treasury and other sections, such as Enderûn-i Humayun and Hasahır (Royal Stables), Cebehâne-i Âmire and Mehterhâne-i Âmire, provided that he should return them after his mission had been completed. These were: a diamond ring seal, a jewelled dagger, a jewelled sword, a jewelled inkwell, a jewelled cup holder, four horses, various horse harnesses adorned with jewels and precious fabrics, four swords, jug set, a tent set, a spear and an umbrella. ${ }^{10)}$ In one of the documents, it is also mentioned that a travel allowance of 6.000 kurus was provided. ${ }^{11)}$ Lending valuable things such as these to the envoys was

8) Hitzel (2010:251).

9) Reychman (1964a:17); Topaktaş (2014: 30-31).

10) BOA, CH., 5954, 27 Ra 1191 (4-5 May 1777); BOA, CH., 5728, 3 Z 1191 (3 December 1777); BOA, AE. SABH.İ., 762, 1191 (1777).

11) BOA, CH., 5954, 27 Ra1191 (4-5 May 1777). 
a custom of the Ottoman Court. The reason for this, was that the envoy could reflect the power and glory of the Ottomans in the land where he was sent. Although we cannot precisely clarify from the documents when Numan Bey started his journey to Warsaw, it can be said that the preparation for the trip took place at the beginning of May, 1777.

Together with a letter, some gifts were given to Sayyid Numan Bey, to be presented to the Polish king on behalf of Sultan Abdulhamid I. In an archival document, dated 29 December, 1777, the list of gifts is as follows in table (Fig. 1). ${ }^{12)}$

\begin{tabular}{|c|c|c|c|}
\hline $\begin{array}{l}\text { Horse and } \\
\text { Carthorse }\end{array}$ & $\begin{array}{c}\text { Items related to } \\
\text { horses }\end{array}$ & Clothing and Fabrics & Other \\
\hline $\begin{array}{l}1 \text { Horse } \\
\text { (From Royal Stables) }\end{array}$ & $\begin{array}{l}1 \text { silver gilded saddle } \\
\text { and barding } \\
\text { (From Royal Stables) }\end{array}$ & $\begin{array}{l}3 \text { gold thread } \\
\text { handkerchiefs } \\
\text { (From the Treasure) }\end{array}$ & $\begin{array}{l}30 \text { agar wood } \\
\text { scents } \\
\text { (From the Treasure) }\end{array}$ \\
\hline $\begin{array}{l}1 \text { Horse } \\
\text { (From Royal Stables) }\end{array}$ & $\begin{array}{l}1 \text { silver gilded barding } \\
\text { (From Royal Stables) }\end{array}$ & $\begin{array}{l}10 \text { gold thread wool } \\
\text { ihrams } \\
\text { (From the Treasure) }\end{array}$ & $\begin{array}{l}2 \text { silver topped } \\
\text { crystal bottles } \\
\text { (From the Treasure) }\end{array}$ \\
\hline $\begin{array}{l}1 \text { Horse with black } \\
\text { ear lock } \\
\text { (From Palace Stables) }\end{array}$ & $\begin{array}{l}1 \text { silver gilded bridle } \\
\text { (From Palace Stables) }\end{array}$ & $\begin{array}{l}10 \text { Dresses made in } \\
\text { İstanbul } \\
\text { (From the Treasure) }\end{array}$ & \\
\hline $\begin{array}{l}1 \text { Horse in the 'colour } \\
\text { of a squirrel' } \\
\text { (From Royal Stables) }\end{array}$ & $\begin{array}{l}3 \text { silver gilded horse } \\
\text { bags } \\
\text { (From Royal Stables) }\end{array}$ & $\begin{array}{l}10 \text { rolls of lined floral } \\
\text { fabrics } \\
(B a b-\imath \text { Ali) }\end{array}$ & \\
\hline \multirow[t]{6}{*}{$\begin{array}{l}1 \text { Carthorse } \\
\text { (From Royal Stables) }\end{array}$} & $\begin{array}{l}1 \text { silver gilded stirrup } \\
\text { (From Royal Stables) }\end{array}$ & $\begin{array}{l}10 \text { lined printed fabrics } \\
(\text { Bab- }- \text { Ali) }\end{array}$ & \\
\hline & $\begin{array}{l}2 \text { silver lined White } \\
\text { silk fabrics } \\
\text { (From Palace Stables) }\end{array}$ & $\begin{array}{l}10 \text { Rolls of silk fabrics } \\
\text { made in İstanbul } \\
(B a b-\imath \text { Ali) }\end{array}$ & \\
\hline & $\begin{array}{l}2 \text { silver coated silk } \\
\text { saddles } \\
\text { (From Palace Stables) }\end{array}$ & $\begin{array}{l}10 \text { colour sof (a woollen } \\
\text { cloth) } \\
(B a b-l \text { Ali) }\end{array}$ & \\
\hline & $\begin{array}{l}2 \text { bridles and felts } \\
\text { (From Royal Stables) }\end{array}$ & $\begin{array}{l}10 \text { colour bunting sof } \\
\text { (a woollen cloth) } \\
\text { (Bab-l Ali) }\end{array}$ & \\
\hline & $\begin{array}{l}2 \text { yellow broadcloth } \\
\text { lined horse shirts } \\
\text { (From Royal Stables) }\end{array}$ & & \\
\hline & $\begin{array}{l}2 \text { European silk } \\
\text { broadcloths } \\
\text { (From Palace Stables) }\end{array}$ & & \\
\hline
\end{tabular}

12) BOA, TS.MA.d, 24220016, 29 Z 1191 (29 December 1777). 
When we study the table above, we see that the gifts are divided into 4 main groups. These consist of horses, items related to horses, clothing and fabrics and other goods, such as scents and bottles. The amount of the gifts, and the places where they are taken from, are also specified in the document.

According to research carried out to date, there is no journal written by Numan Bey. However, the tradition of writing journals by the envoys appointed in the second half of the 18th century, suggests the possibility that he also wrote one. On the other hand, when the documents in the Polish archives related to Numan Bey, and the journals by his host and Polish royal translator, are deciphered, many details will be unveiled about his stay in Warsaw as an envoy. ${ }^{13)}$ One of the little known facts concerning this trip, is that the delegation led by Numan Bey was welcomed with great interest by the public in Poland and revived Turkish fashion there. Furthermore, it is known that the envoy was fasting during Ramadan, and on the feast days following, fireworks were set off, according to the diaries in the Polish archives. In the same diary, it is written that he got tickets for himself and the delegation for a masquerade in Warsaw. In addition, a local newspaper mentioned him as: "being a good Muslim, he went back to his country touching the hearts of the people with his exemplary behaviour" ${ }^{14)}$

Numan Bey didn't return empty-handed from Warsaw. He was given a dinner set by the Polish King Poniatowski to present to Sultan Abdulhamid I. Known as 'the Sultan set' in some Polish sources, ${ }^{15)}$ this set of dishes is of interest for the history of pottery and porcelain. In an archive document dated 6 June, 1778, ${ }^{16)}$ the features and the number of the set are stated. From the document, it is also noted that: "the set was produced in Warsaw, Poland, in the Royal Factory" (Fig. 2).

According to the archival document related to the dinner set in the Topkapi Palace Collection, it consists of 160 pieces. But in the palace inventory, only 52 pieces are registered. ${ }^{17)}$ The list in the archive document is as follows:

\footnotetext{
13) Topaktaş (2014:218).

14) Topaktaş (2011:32-33).

15) Reychman (1964b: 141).

16) BOA., TS.MA.d, 3360, 10 Ca.1192 ( 6 June1778).

17) Tufan (2013: 190); Tufan (2014: 304-305).
} 


\begin{tabular}{|c|c|c|c|c|}
\hline $\begin{array}{l}\text { Large containers } \\
\text { and plates } \\
4 \text { pieces }\end{array}$ & $\begin{array}{l}\text { Medium-sized } \\
\text { containers } \\
4 \text { pieces }\end{array}$ & $\begin{array}{l}\text { Large, round } \\
\text { plates } \\
4 \text { pieces }\end{array}$ & $\begin{array}{l}\text { Large, round } \\
\text { plates } \\
8 \text { pieces }\end{array}$ & $\begin{array}{l}\text { Large, round plates } \\
16 \text { pieces }\end{array}$ \\
\hline $\begin{array}{l}\text { Large, round } \\
\text { plates } \\
20 \text { pieces }\end{array}$ & $\begin{array}{l}\text { Plates and } \\
\text { bowls } \\
12 \text { pieces }\end{array}$ & $\begin{array}{l}\text { Large, egg } \\
\text { shaped plates } \\
8 \text { pieces }\end{array}$ & $\begin{array}{l}\text { Egg-shaped, } \\
\text { medium-sized } \\
\text { plates } \\
16 \text { pieces }\end{array}$ & $\begin{array}{l}\text { Containers to keep } \\
\text { diamond, gold and } \\
\text { silver ornaments } \\
16 \text { pieces }\end{array}$ \\
\hline $\begin{array}{l}\text { Egg-shaped } \\
\text { basket and small } \\
\text { plates } \\
8 \text { pieces }\end{array}$ & $\begin{array}{l}\text { Egg-shaped } \\
\text { basket and small } \\
\text { plates } \\
8 \text { pieces }\end{array}$ & $\begin{array}{l}\text { Containers for } \\
\text { food } \\
24 \text { pieces }\end{array}$ & $\begin{array}{l}\text { Salt cellars } \\
12 \text { pieces }\end{array}$ & \\
\hline
\end{tabular}

Missing pieces of the set have either been broken or registered to some other people in the course of time. Some examples of the remaining pieces are on display in the Topkapi Palace kitchen section. From the existing pieces in the palace inventory, it is understood that the dinner set was made from a soft kind of porcelain. In this respect, they can be categorized as 'ceramics'. All components have the same decorative pattern, which features an imitation of the Imari style in Japanese porcelain. ${ }^{18)}$

As far as is known, Japanese Imari style porcelain started to be produced in Arita, mainly in the late 17 th century and 18 th century. ${ }^{19)}$ After applying cobalt blue to the desired place under the transparent glaze, they were fired with high heat. Then, the porcelain was fired for a second time at a lower temperature, after applying gilt, red and other colours, on the glaze. A large proportion of this type of porcelain was made to be exported to Europe. As from the end of the 17th century, imitations of Imari porcelain were made in the kilns of Jingdezhen, China. Thereby, China became part of the European market. During the 18th and 19th century, both Japanese and Chinese products were imitated in Europe. ${ }^{20)}$

The pattern on the pieces of the Warsaw porcelain sent to Abdulhamid I is seemingly a copy of the Chinese Imari pattern. The same pattern is seen on a pair of plates of Jingdezhen production, belonging to the beginning of the 18th century, in the collections of the Victoria and Albert Museum (Inv. no.

18) Tufan ( 2013: 190-191); Tufan (2014:304-305).

19) Klein (1987:114).

20) Savage-Newman (1975: 155); Morkey-Fletcher (1997:105). 
C.1474-1910) ${ }^{21)}$ and the Metropolitan Museum of Art (Inv. no. 1995.268.35).22) The main difference between the two sets of wares is the existence of inscribed cartouches in Topkapi Palace samples.

The pattern of the dinner set belonging to Sultan Abdulhamid I is coloured with cobalt blue, green, red, yellow and gilt on a white background. The patterns consist of flower-like chrysanthemum and peony, and trees, birds and butterflies, in the Far Eastern style. On the bottom of containers in the form of plates, cartouche patterns are noteworthy. There are some Ottoman calligraphic inscriptions written using thuluth technique in five different cartouches. In the central cartouche, "Be makâm-1 Varşova" can be read, and in the surrounding cartouches: "Âl-i Osmân Pâdişâhına", "Leh kralı kemâli sıdk-1 muhabbet", "ve hulûs izhârı içün", "iş bu ihdâ ithaf ve irsâl eder". In the other pieces of the set, these were repeated. ${ }^{23)}$ (Figs. 3-4) These inscriptions imply that the pieces were made in Warsaw and sent to Sultan Abdulhamid I. to establish friendship on behalf of the Polish king. Inscriptions were stated to have been written by a translator called Crutta in Warsaw. ${ }^{24)}$ Antoni Łukasz Crutta (1727-1812), was a Venetian who was born in Albania. From 1765 until dissolution of the Commonwealth, he served as the Ottoman interpreter of King Ponitowski. It is known that he led Numan Bey's envoy mission to Poland and wrote a travel diary. In 1779, French painter Jean-François Duchateau made portraits of Crutta and his wife. In this portrait Crutta is shown in traditional Ottoman interpreter costume. On the inscribed paper he holds in hand, although the inscription is not clear, is thought to be written: "Turkish and Arabic translator" (Fig.5). ${ }^{25)}$

Both from the archival document mentioned above and the cartouches on the dining set, we learn that the ceramics were produced in the royal factories in Warsaw. Inside some lids of the set, stamps can be seen indicating the production centre. This stamp is composed of the text "Varsovie" and belongs to the Belvedere Factory (Fabrika Belwederska). King Poniatowski founded this factory in Warsaw in $1774 .{ }^{26)}$ However porcelain production was not

\footnotetext{
21) http://collections.vam.ac.uk/item/O168468/dish-unknown/ , 19.03.2015.

22) http://www.metmuseum.org/search-results\#!/search?q=1995.268.35\&page=1, 19.03.2015.
23) Tufan ( 2013:191); Tufan (2014: 304-305).
24) Reychman (1964b: 141).
25) Małachowicz (1999: 246): Małachowicz (2014: 301).
26) Cushion (1980: 230). 
possible due to production difficulties, and goods that could be described as ceramics, for their softer clay, were produced instead. The factory production was labelled as 'Varsovie'. The general style of decoration was inspired by ceramics, both from the Far East, China and Japan, but also from the FarEastern influenced Dutch and German ceramics. This factory was closed in $1783 .{ }^{27}$

The plates, which certainly belong to the set sent to Sultan Abdul Hamid I., are in the collections of the Victoria and Albert Museum (Inv. no. 544-1897), ${ }^{28)}$ the Metropolitan Museum of Art (Inv. no. 50.211.277)29) and National Museum in Krakow (Muzeum Narodowe w Krakowie, Inv. no: MNK-IV-C-3943). ${ }^{30}$ These examples provide us with a clue as to where some of the missing parts of the 160-piece ceramics set, as stated in the Ottoman archival records, are located. Probably, these pieces were taken out of the Topkapi Palace and transferred to European collections at the end of the 19th century or first half of the 20th century.

This porcelain set sent exclusively to Sultan Abdul Hamid I by King Poniatowski, as far as is known, was the first European-style dining set in the Topkapi Palace. It may be understood from the rich diversity of the porcelain collection, that the number of these European sets had increased over time in the Topkapi Palace. The majority of porcelain in the palace collection was given as presents. One purpose of these gifts might have been to please the Sultan and his entourage, while another might have been to introduce the products of European producers to the eastern market.

Whether as a 'bribe' or as a 'present' to conclude some issues, or a symbol of might and wealth, or a showcase of the goods from large factories, the gifts offered between countries should be considered as primary sources of cultural interaction. The gifts and costumes brought to Europe by Ottoman embassies and their attitudes and customs, had given rise to a taste for Turkish culture in Europe, notably in 18th century. Ordering portraits in Turkish costumes became a trend and Turkish motifs came into various areas such as literature, performing arts, painting and decoration. ${ }^{31)}$

27) Reychman (1964b, 140,142).

28) http://collections.vam.ac.uk/item/O160687/plate-belvedere-factory/ , 19.03.2015.

29) http://www.metmuseum.org/search-results\#!/search?q=50.211.277\&page=1,19.03. 2015.

30) Kostuch (2011: 348-349).

31) Renda (2003: 1109-1110). 
Poland projects a good example of this. The Ottoman artefacts in present day Polish collections are a reflection of the good long-term diplomatic relations between the two countries. It is known that these objects, consisting of fabrics, weapons and harnesses, came into Poland mostly as gifts by other means, such as trade and war booty, ${ }^{32)}$ as we can trace in the diaries of delegations and archive documents. ${ }^{33)}$ It is thought that, between the 16th and 18th centuries, there had been a great curiosity toward those objects among the aristocracy. The products from Ottoman soil did not meet this demand, therefore, in a short while, local production in Poland had begun to produce copies of those goods. ${ }^{34)}$ This has resulted in a strong Ottoman influence in Polish handicrafts.

In the case of the Ottoman Empire, the changes referred to as 'the Westernization' of Turkish culture and art in the 18th century, can be said to have been caused primarily by European goods that entered the palace. Books, engravings, architectural drawings, watches, furniture, tools, fabrics and porcelain which came into Ottoman land, mostly as gifts from several centres of Europe, transported the dominant styles and fashions of the period. These not only caused the transfer of styles between cultures, but also changed the habits of society.

A majority of western emissaries to the Ottoman palace brought valuable porcelain, a great part of them produced specially for Ottoman sultans. ${ }^{35)}$ The ceramics that have been described here, and the high-quality porcelain that entered the palace as gifts as well, both in form and in function, played an important role in changing the eating and drinking habits in Turkish palace culture. The porcelain which came in traditional forms, such as the sahan (shallow frying pan), wash-bowl and pitchers in the beginning, made their way into large European style dining sets, containing sauce-bowls, ice cream cups and ice-bowls. With the introduction of European-style furniture to the court of the Ottomans, either as gifts or as commissions, eating around a table became the new custom. ${ }^{36)}$

\footnotetext{
32) Majda (1999: 48-49).

33) See Anafarta (1979).

34) Majda (1999: 50).

35) Sonat (2005:14).

36) Coşansel Karakullukçu (2007: 34-35).
} 


\section{BIBLIOGRAPHY}

Anafarta (1979) = Nigâr Anafarta (haz.), Osmanlı İmparatorluğu ile Lehistan (Polonya) Arasindaki Münasebetlerle İlgili Tarihi Belgeler (Historical Documents on Relations between Ottoman Empire and Poland), İstanbul 1979.

Coşansel Karakullukçu (2007) = Demet Coşansel Karakullukçu, 150 Yllın Sessiz Tanıkları: Saray Porselenlerinden İzler (The Silent Witnesses of 150 Years : Traces of the Palace Porcelain), İlona Baytar (ed.), exhibition cat., BMM Milli Saraylar Daire Başkanlığı, İstanbul 2007.

Cushion (1980) = J.P. Cushion (compiler): Handbook of Pottery and Porcelain Marks, London 1980.

Hitzel (2010) = Frédéric Hitzel: "Diplomatik Armağanlar: Osmanlı İmparatorluğu ile Batı Avrupa Ülkeleri Arasında Modern Çağda Yapılan Kültürel Değiş Tokuş”( Diplomatic Gifts: Cultural Exchange Between Ottoman Empire and Western European Countries in Modern Era), Harp ve Sulh: Avrupa ve Osmanllar (War and Peace: Europeans and Ottomans), Dejannirah Couto (ed.), İstanbul 2010: 243-257.

Klein (1987) = Adalbert Klein, $A$ Connoisseur's Guide to fapanese Ceramics, London 1987. Kołodziejczyk (1999) = Dariusz Kołodziejczyk, "Polonya ve Osmanlı Devleti Arasında Tarih Boyunca Siyasi ve Diplomatik İlişkiler”(A Historical Outline of Polish - Ottoman Political and Diplomatic Relations), Savaş ve Barış: 15-19. Yüzyll Osmanlı Lehistan İlişkileri (War and Peace: Ottoman - Polish Relations in the 15th - 19th Centuries), exhibition cat., Turkish and Islamic Art Museum, İstanbul 1999: 21-33.

Kostuch (2011) = Bozena Kostuch, "Plate from the Sultan Set" Polonia. Tesoros y Colecciones Artisticas, exhibition cat., Madrid 2011, 348-349.

Majda (1999) = Tadeusz Majda, "Polonya Koleksiyonlarında Osmanlı Sanatı" (Ottoman Art in the Polish Collections), Savaş ve Barış: 15-19. Yüzyll Osmanl__Lehistan İlişsileri (War and Peace: Ottoman - Polish Relations in the 15th - 19th Centuries), exhibition cat., Turkish and Islamic Art Museum, İstanbul 1999: 47-51.

Majda (2014) = Tadeusz Majda, “Osmanlı Sarayı'nda Huzura Kabul Edilen Lehistan Elçilerinin İkonografik Temsilleri” (Iconographic Representations of Audiences of Polish Envoys To The Ottoman Court), Uzak Komşu Yakın Anılar: Türkiye Polonya İlişkilerinin 600 Yll (Distant Neighbour Close Memories : 600 Years Of Turkish Polish Relations), Ayşen Anadol (ed.), exhibition cat., Sakıp Sabancı Museum, İstanbul 2014: 78-85.

Małachowicz (2014) = Hanna Małachowicz, "Antoni Łukasz Crutta Portresi, Maria Catziflis De Christophori Crutta Portresi” (Portrait of Antoni Lukazs Crutta, Portrait of Maria Catziflis De Christophori Crutta), Uzak Komşu Yakın Anılar: Türkiye Polonya İlişkilerinin 600 Yll l(Distant Neighbour Close Memories: 600 Years Of Turkish Polish Relations), Ayşen Anadol (ed.), exhibition cat., Sakıp Sabancı Museum, İstanbul 2014: 301.

Morkey-Fletcher (1997) = Hugo Morkey-Fletcher (ed.), Techniques of the World's Great Masters of Pottery and Ceramics, New Jersey 1997.

Topaktaş (2011) = Hacer Topaktaş, "Osmanlı'nın Süferâsı"(Ottoman Emissaries) Mostar, 72, 2011:30-33. 
Topaktaş $(2014)=$ Hacer Topaktaş, Osmanlı-Lehistan Diplomatik İlişkileri, Franciszek Piotr Potocki’nin İstanbul Elçiliği (1788-1793) (Polish-Ottoman Diplomatic Relations: Istanbul Embassy of Franciszek Piotr Potocki), Ankara 2014.

Tufan (2013) = Ömür Tufan, "Sultanların Sofrasını Süsleyen Topkapı Sarayı'ndaki Avrupa Porselenleri” (European Porcelains Adorning Sultans Table in Topkapı Palace) Topkapı Sarayı Müzesi Yıllık (Topkapı Palace Annual), 6 (2013:186-203).

Tufan (2014) = Ömür Tufan, "Sultan I. Abdülhamid'in Varsovie Damgalı Yemek Takımı”(Varsovie Stamped Dinner Set of Sultan Abdulhamid I), Uzak Komşu Yakın Anılar: Türkiye Polonya İlişkilerinin 600 Yılı (Distant Neighbour Close Memories : 600 Years Of Turkish Polish Relations), Ayşen Anadol (ed.), exhibition cat., Sakıp Sabancı Museum, İstanbul 2014: 304-305.

Renda (2003) =Günsel Renda, "Sanatta Etkileşim"(Interactions in Art), Osmanlı Uygarlı̆̆1 (Ottoman Civilization), v.2, Halil İnalcık (ed.), İstanbul 2003:1091-1121.

Renda (2014) = Günsel Renda, "Osmanlı'da Diplomatik İlişkiler: Elçiler ve Portreleri" (Diplomatic Relations in the Ottoman Empire: Ambassadors and Portraits), Kesişen Dünyalar: Elçiler ve Ressamlar (Intersecting Worlds: Ambassadors and Painters), exhibition cat., Pera Museum, İstanbul 2014: 37-43.

Reychman (1964a) = Jan Reychman, Polonya ile Türkiye Arasında Diplomatik Münasebetlerin 550. Yıldönümü (550th Anniversary of Diplomatic Relations Between Poland and Turkey), Ankara 1964.

Reychman (1964b) = Jan Reychman, Orient $w$ kulturze polskiego Oświecenia (Orient in the Culture of the Polish Enlightenment), Wroclaw 1964.

Savage-Newman (1974) = George Savage, An Illustrated Dictionary of Ceramics, London 1974.

Sonat $(2005)$ = Göksel Sonat, “Topkapı Sarayı Müzesi’ndeki Osmanlı Zevkiyle Yapılmış Avrupa Porselenleri” (European Porcelain made with Ottoman Taste in Topkap1 Palace Museum), Osmanl Sarayında Avrupa Porselenleri (European Porcelains in Ottoman Palace), exhibition cat., Sakıp Sabancı Museum, İstanbul 2005:13-19.

Unat (1987) = Faik Reşit Unat: Osmanlı Sefirleri ve Sefaretnameleri (Ottoman Emissaries and Their Journals), Ankara 1987.

\section{PRIMARY SOURCES}

\section{BOA (Başbakanlık Osmanlı Arşivi (The Ottoman Archives of the Prime Minister's Office)}

BOA, CH., 5954, 27 Rabiulevvel 1191 (4-5 May 1777).

BOA, CH., 5728, 3 Zilkade 1191 (3 December 1777).

BOA, AE. SABH.İ., 762, 1191 (1777).

BOA, TS.MA.d, 24220016, 29 Z 1191 (29 December 1777).

BOA., TS.MA.d, 3360, 10 Ca.1192 ( 6 June 1778). 


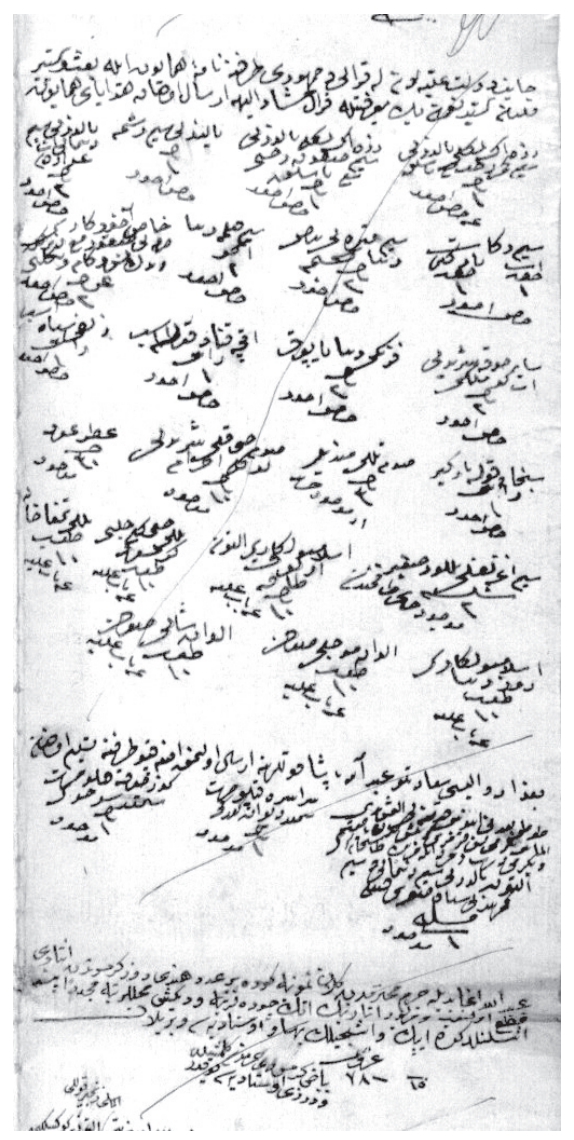

Fig. 1. An archival document related to some gifts given to Sayyid Numan Bey (BOA, TS.MA.d, 24220016, 29 Z 1191 (29 December 1777)

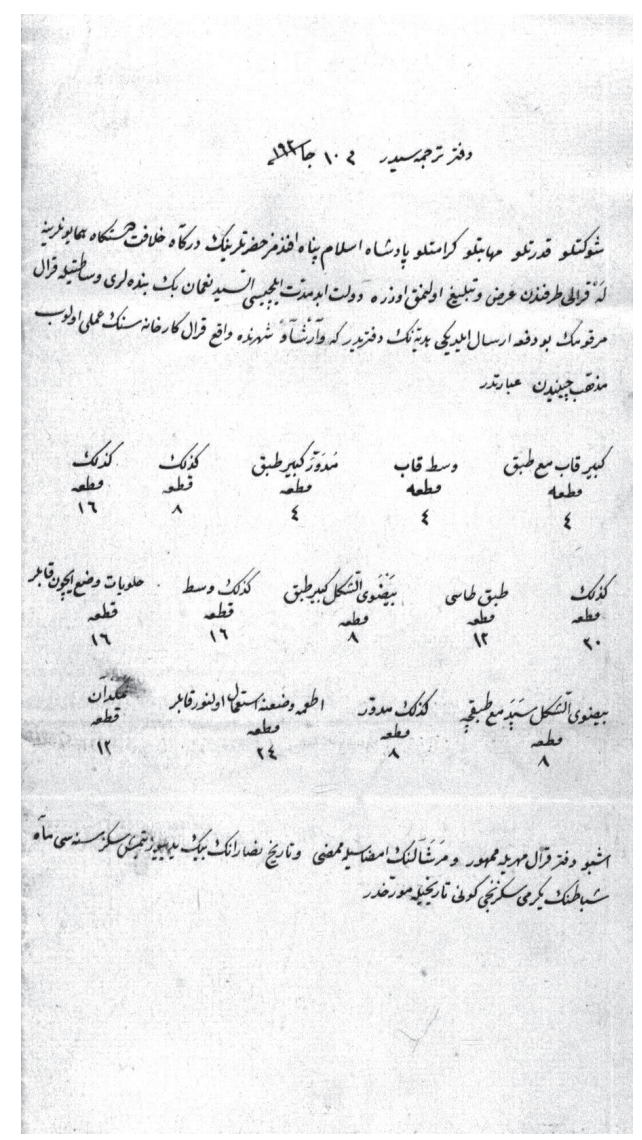

Fig. 2. An archival document related to the dinner set in the Topkapi Palace (BOA., TS.MA.d, 3360, 10 Ca.1192 ( 6 June 1778) 


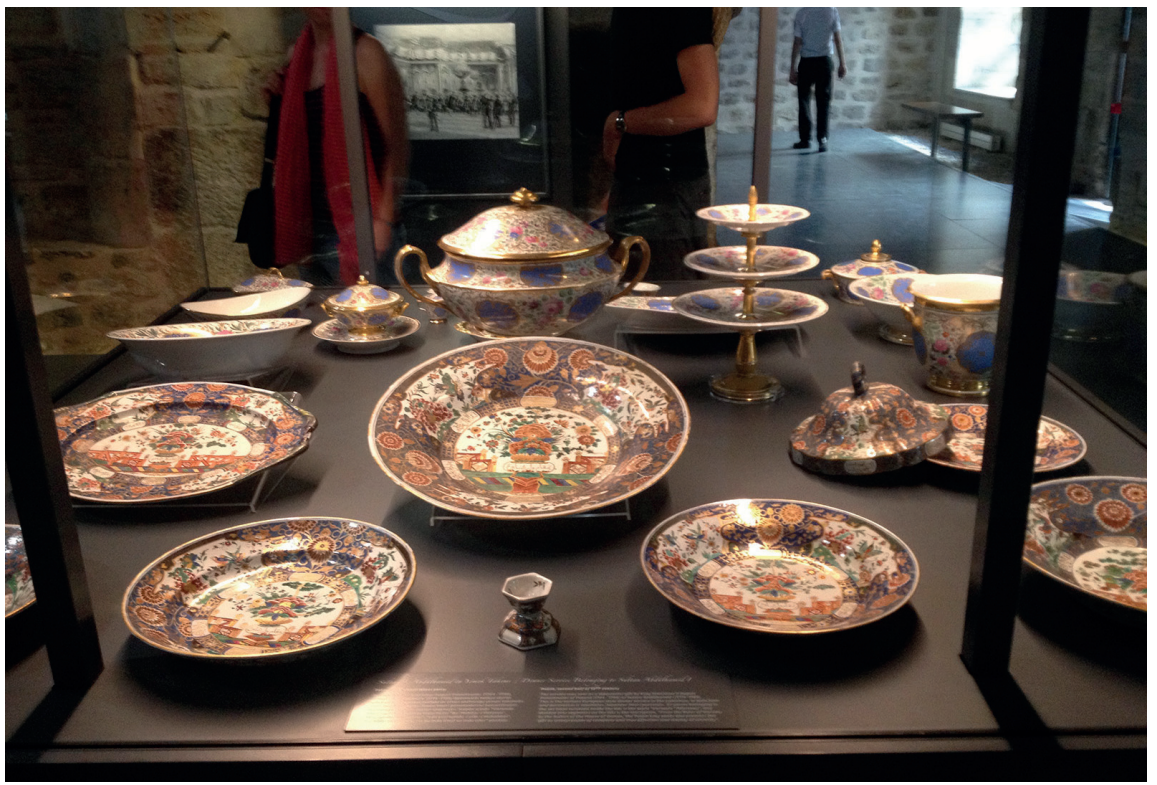

Fig. 3. Some examples of the dinner set (Sultan set) on display in the Topkapi Palace kitchen section

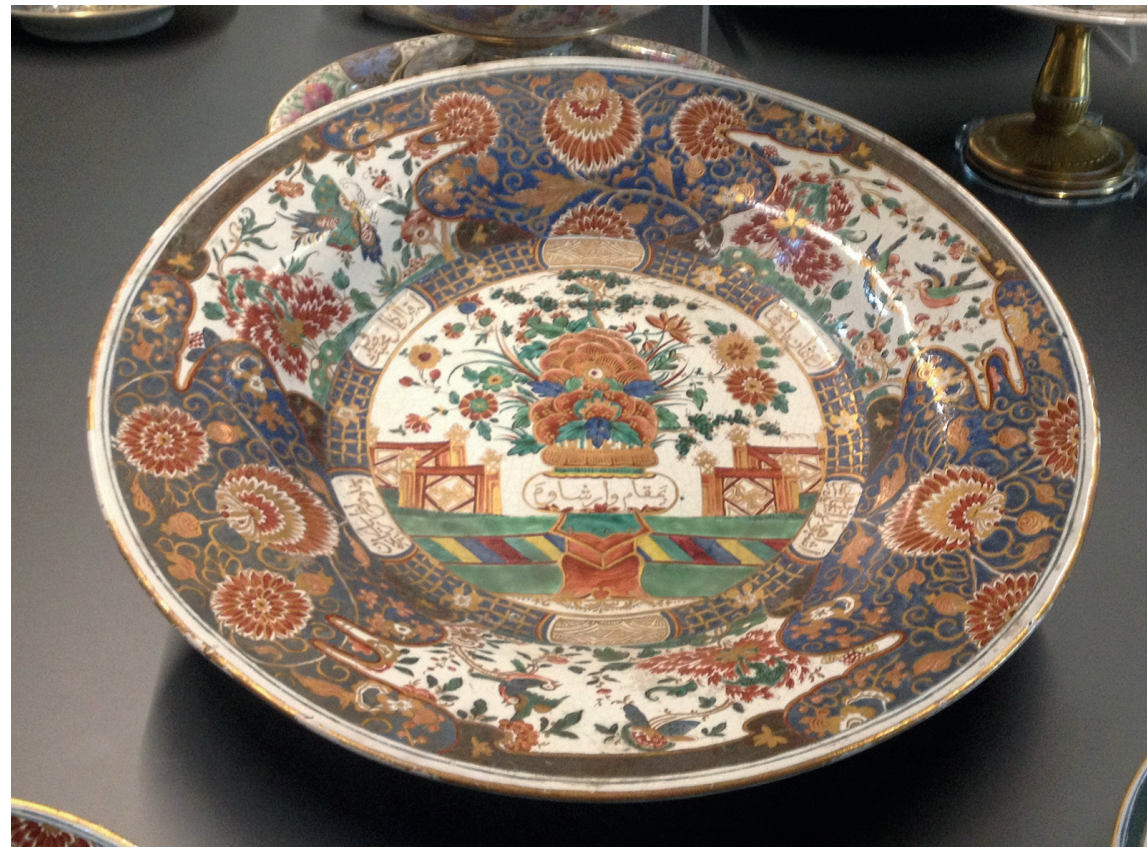

Fig. 4. One plate of the dinner set (Sultan set) on display in the Topkapi Palace kitchen section 


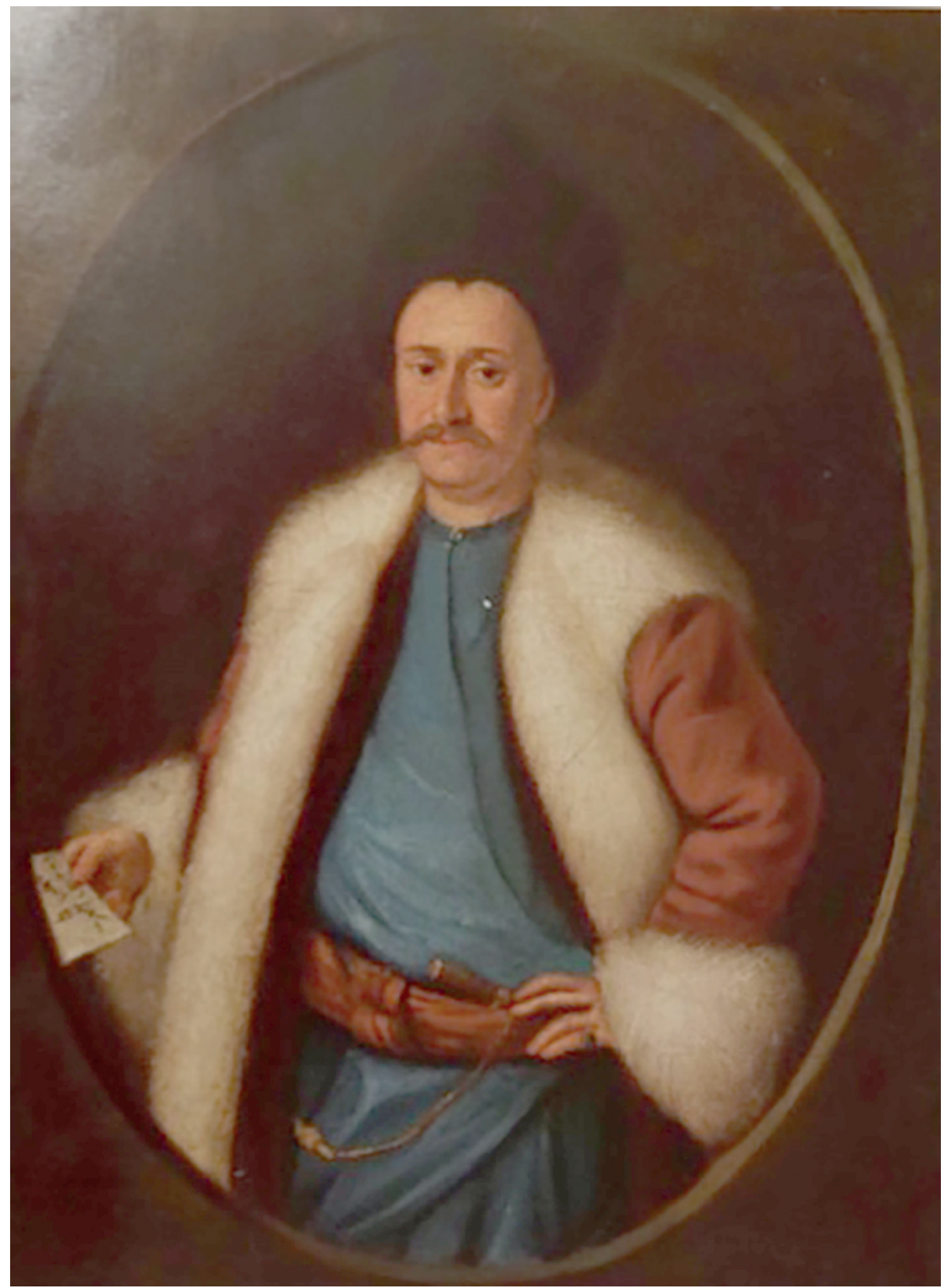

Fig. 5. Portrait of Antoni Łukasz Crutta (Małachowicz (2014: 301) 